\title{
Influence of Curing Procedures on the Electrical Properties of Epoxy-Based Isotropic Conductive Adhesives
}

\author{
Xiong Nana ${ }^{1}, \quad$ Li Zhiling ${ }^{1}, \quad$ Xie Hui $^{2}, \quad$ Zhao Yuzhen $^{3}, \quad$ Wang Yuehui $^{2}, \quad$ Li Jingze ${ }^{1}$
}

${ }^{1}$ State Key Laboratory of Electronic Thin Films and Integrated Devices, University of Electronic Science and Technology, Chengdu 610054, China; ${ }^{2}$ University of Electronic Science and Technology of China Zhongshan Institute, Zhongshan 528402, China; ${ }^{3}$ Tsinghua University, Beijing 100084, China

\begin{abstract}
A typical isotropic conductive adhesives (ICAs) composed of an epoxy-based binder containing micro-sized silver flakes was prepared and the effects of different curing procedures on the electrical properties of the ICAs were investigated. The results show that there is greater influence of the curing temperature on $55 \mathrm{wt} \%$ silver loading, the volume resistivity of ICAs decreases to $4.5 \times 10^{-3} \Omega \cdot \mathrm{cm}$ from $5.2 \times 10^{-2} \Omega \cdot \mathrm{cm}$ cured at 250 and $180^{\circ} \mathrm{C}$, respectively. However, there is almost no effect on the high silver loading. The variations in electrical resistance of the ICAs with $65 \mathrm{wt} \%$ silver loading was in situ monitored during the curing process, and it is found that the resistance reaches to $1.99 \times 10^{6} \Omega$ at $180{ }^{\circ} \mathrm{C}$ after cured for $27 \mathrm{~min}, 1.39 \times 10^{-3} \Omega$ for $40 \mathrm{~min}$, and $18.8 \Omega$ for $60 \mathrm{~min}$ and the cooling process has almost no effect on the electrical resistance of the ICAs. The reasons for the dependence of the bulk resistivity on temperatures were also discussed in terms of the dispersing of the silver flakes in ICAs by SEM.
\end{abstract}

Key words: isotropic conductive adhesives; curing; volume resistivity; silver flakes

Electrical conductive adhesives (ECAs) as a potential substitution of lead-bearing solders have recently received a lot of attention from the researchers in electronics industry ${ }^{[1-5]}$. Compared with conventional tin-lead solders, the ECAs possess many advantages, such as environmental friendliness, finer pitch printing, lower temperature processing and more flexible and simpler processing ${ }^{[3-8]}$. However, complete replacement of soldering by ECAs is yet not possible owing to several limitations of ECAs which are mainly related to reliability aspects like limited impact resistance, unstable contact resistance, low adhesion, and conductivity.

Isotropic conductive adhesives (ICAs), the major type of ECAs, are composed of polymeric binders (which provide mechanical strength) and conductive fillers (which act as channel for charge transport). The characteristics of an ICA are essentially the result of its two components. Epoxy resin is one of the common materials used as polymer matrix in the ICAs. The interconnect properties and reliability of conductive adhesives are determined by the state of cure of the binder ${ }^{[9-14]}$. Therefore, an understanding of factors that affect the relationship between the curing states and the interconnect properties is essential to enable correct choice of curing conditions for conductive adhesives in order to achieve high reliability. Some of the work in literatures detailed the effects of the thermal history on electrical properties of an epoxy-based ICAs, and indicated the curing and post-heating treatment impacted the internal stress of the ICAs, which had a significant effect on the electrical resistivity of the ICAs ${ }^{[9-14]}$. However, academic reports concerning the effects of the curing states still remain inconsistent. 
In the present work, we prepared a typical ICAs composed of an epoxy-based binder containing micro-sized silver flakes and discussed the reasons for the dependence of bulk resistivity on curing procedures.

\section{Experiment}

Diglycidyl ether of bisphenol A (R-128) was purchased from Guangzhou Hongchang Co., Ltd. 4-methylhexahydrophthalic anhydride (MHHPA) and 2-ethyl-4-methylimidazole (2E4MZ) were supplied by Guangtuo Chemical Co., Ltd. Micro-sized silver flakes $\left(\mathrm{SF} 1023 \mathrm{~K}, D_{50}<5 \mu \mathrm{m}, D_{90}<7.0 \mu \mathrm{m}, D_{10}<1.0 \mu \mathrm{m}\right)$ were purchased from Guangdong Fenghua Advanced Technology Group Co., Ltd.

The ICAs were prepared based on the following procedure: R-128, MHHPA and 2E4MZ with a mass ratio of 1:0.85:0.05 were put in a small beaker, and was sonicated for $30 \mathrm{~min}$. Then, the silver flakes were incorporated into the polymer matrix with sonication for another $30 \mathrm{~min}$ to make the fillers uniformly dispersed in mixture. Two strips of polyimide tape were applied onto a pre-cleaned glass slide with a gap width of $1 \mathrm{~cm}$. The formulated composite was bladed into the space between the two strips. The polyimide tapes were removed before curing at the desired temperature and time. The thickness of the cured film was controlled by the polyimide tapes.

Heat generation of ICAs during curing reaction was studied with a differential scanning calorimeter (DSC Q100 V9.5 Build 288) from TA Instruments. An approximately 10 mg sample of an adhesive was placed in a hermetic aluminum DSC pan. In a nonisothermal cure study, the samples were heated in the DSC cell from $25^{\circ} \mathrm{C}$ to $300{ }^{\circ} \mathrm{C}$ at different heat rates of $5,10,15$ and $20^{\circ} \mathrm{C} / \mathrm{min}$ in nitrogen.

All scanning electron microscopy (SEM) images were taken on a JSM-6460. The resistivity of the ICAs was measured using a DMR-1C four-point probe meter (Nanjing Daming instrument Co., LTD). The resistivity, $\rho$, was calculated using the following Eq.(1):

$$
\rho=R_{\mathrm{L}} \omega
$$

where, $R_{\mathrm{L}}$ and $\omega$ are square resistance and thickness of sample, respectively. The thickness of samples was measured by the micrometer gauge.

\section{Results and Discussion}

Fig.1 shows the DSC of the ICAs filled with $65 \mathrm{wt} \%$ silver flasks at different heat rates of $5,10,15$ and $20^{\circ} \mathrm{C} / \mathrm{min}$. The initial curing temperature, the peak exothermic temperature, curing end temperature and the heat rates are abbreviated to $T_{\mathrm{i}}, T_{\mathrm{p}}, T_{\mathrm{e}}$ and $\beta$, respectively ${ }^{[12]}$. With increasing of the heat rates, the initial curing temperature, the peak exothermic temperature and curing end temperature all become higher, and the range of curing temperatures becomes wider. The optimal curing conditions can be obtained by the relationship of the cure temperature of the cure reaction with the heat rates, so the optimal conditions of the ICAs could be estimated from linear extrapolation at heat rate $\beta=0 \mathrm{~K} / \mathrm{min}$, which are also given in Fig. 2 and Table 1. It is well known that the curing time actually decreases with the increase of the curing temperature. The optimal curing temperature of the cure reaction is impacted by the heat rates, so it is very important to control the heat rates during the curing procedure.

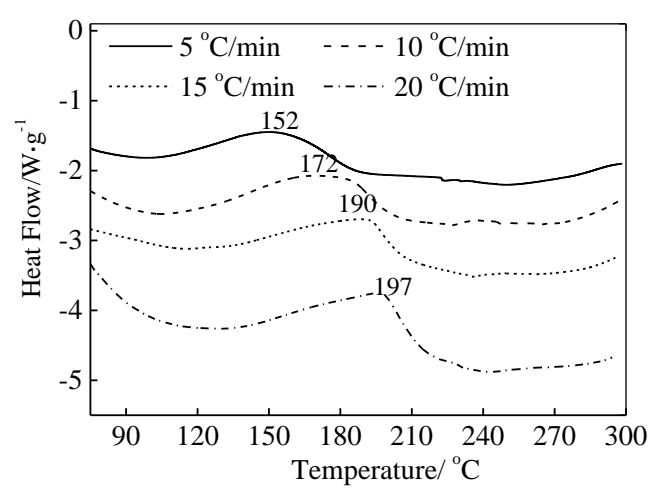

Fig.1 DSC curves of ICAs at different heat rates in nitrogen

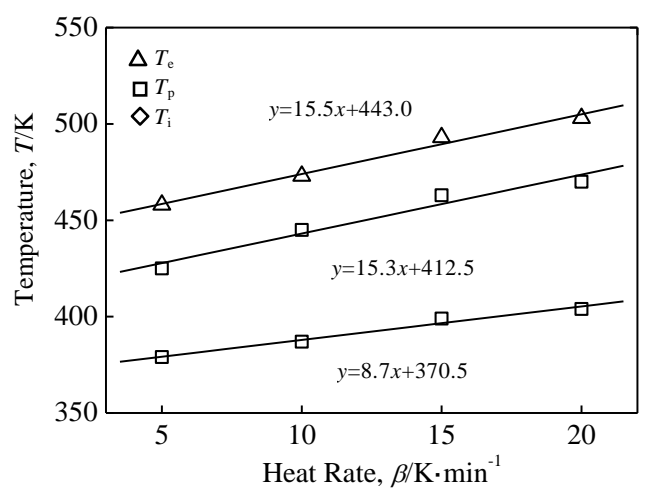

Fig.2 Linear fit curves of the relation between curing temperatures $T$ and heat rates $\beta$

Table 1 DSC results of nonisothermal curing of ICAs at different heat rates

\begin{tabular}{cccc}
\hline$\beta / \mathrm{K} \cdot \min ^{-1}$ & $T_{\mathrm{i}} / \mathrm{K}$ & $T_{\mathrm{p}} / \mathrm{K}$ & $T_{\mathrm{e}} / \mathrm{K}$ \\
\hline 5 & 379 & 425 & 458 \\
10 & 387 & 445 & 473 \\
15 & 399 & 463 & 493 \\
20 & 404 & 470 & 503 \\
0 & 370 & 412 & 443 \\
\hline
\end{tabular}


The electrical resistivity of the ICAs during the curing procedure is one of the most important parameters relating to interconnect reliability and is expected to be realized by the curing reaction ${ }^{[9-12]}$. In order to explore the relationship between the resistance and the curing temperature, the variation in electrical resistance of ICAs filled with $65 \mathrm{wt} \%$ silver flakes is situ monitored during the curing process, as shown in Fig.3. When heated until to $27 \mathrm{~min}$, the resistance of the ICAs is monitored and reaches $1.99 \times 10^{6} \Omega$, and now the temperature is $180{ }^{\circ} \mathrm{C}$. It is indicated that the conductive pathways between the filler particles during the curing process begin to form. It should be pointed out that the curing reaction of the binder has already begun. The resistance reaches $1.39 \times 10^{-3} \Omega$ for $40 \mathrm{~min}$. As the curing time increases to $42 \mathrm{~min}$, the resistance significantly decreases $702 \Omega$. Since then, the resistance gradually decreases to $18.8 \Omega$ for $60 \mathrm{~min}$. The resistance slight decreases to $8.68 \Omega$ during the cooling process from the curing temperature to $170{ }^{\circ} \mathrm{C}$. Thereafter, the electrical resistivity tends toward a constant value during the cooling process from $170{ }^{\circ} \mathrm{C}$ to room temperature.

The formation of electrical conduction paths in the ICA is considered to be closely related to the curing reaction ${ }^{[10-12]}$. The contact resistance at the interfaces between filler particles is considered to be strongly influenced by the contact stress that is generated due to the shrinkage occurring during curing of the adhesive binder ${ }^{[10-14]}$. As the curing time increases, the resistance of the ICAs decreases, and the results could be attributed to the phenomenon that the crosslinking reaction of epoxy resin is gradually intensified, and the curing shrinkage leads to an increase in the contact area between the fillers to promote the formation of conductive pathways between the filler particles during the curing process ${ }^{[10-12]}$. However, when the ICAs are fully cured, the cooling process almost has

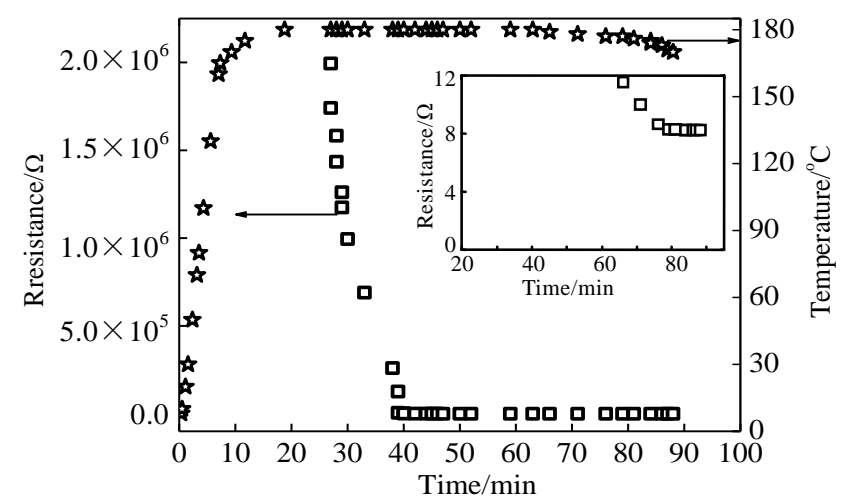

Fig.3 Variations in electrical resistivity in situ monitoring during curing and cooling processes at $180{ }^{\circ} \mathrm{C}$ (the inset is the local amplification) no effect on the electrical resistance of the ICAs, that is to say, it has no significant effect on the distribution and the morphology of silver particles.

Fig. 4 shows SEM images of the in situ monitoring of the ICAs at 30, 40, 60, and $85 \mathrm{~min}$, It is clear that the distribution of silver flakes is uniform, and gradually become compact with increasing of the curing time.

Fig.5 shows the curing temperature dependence of resistivity of the ICAs with $55 \mathrm{wt} \%, 65 \mathrm{wt} \%$ and $75 \mathrm{wt} \%$ filling loading. As shown in Fig.5, with increasing of filling loading of silver flakes and the curing temperature, the resistivity of the ICAs decreases. The curing temperature has a greater influence on the ICAs with filling loading of $55 \mathrm{wt} \%$. Along with increasing of the curing temperature, the volume resistivity of ICAs decreases to $4.5 \times 10^{-3} \Omega \cdot \mathrm{cm}$ from $5.2 \times 10^{-2} \Omega \cdot \mathrm{cm}$ cured at $180{ }^{\circ} \mathrm{C}$ and $250{ }^{\circ} \mathrm{C}$, respectively. It could be attributed to the enhancement of the curing shrinkage under this condition, and it is advantageous to promote the formation of the conductive pathways $^{[14]}$.

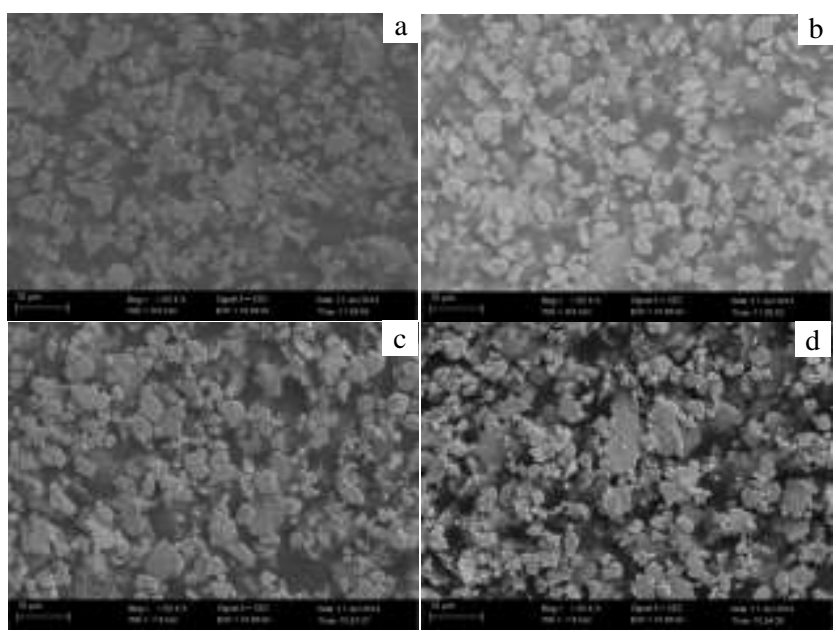

Fig.4 SEM images of the in situ monitoring of the ICAs at 30 $\min (\mathrm{a}), 40 \mathrm{~min}(\mathrm{~b}), 60 \mathrm{~min}(\mathrm{c})$, and $85 \mathrm{~min}(\mathrm{~d})$

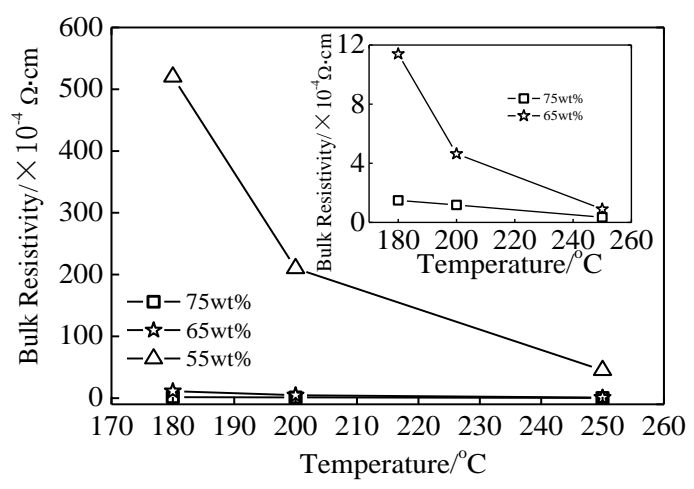

Fig.5 Curing temperature dependence of resistivity of the ICAs with $55 \mathrm{wt} \%, 65 \mathrm{wt} \%$ and $75 \mathrm{wt} \%$ filling loading (the inset is the local amplification) 
Fig.6 shows SEM images of the ICAs filled with the loading of $55 \mathrm{wt} \%, 65 \mathrm{wt} \%$ and $75 \mathrm{wt} \%$ silver flakes cured at $180{ }^{\circ} \mathrm{C}$. When the loading is $55 \mathrm{wt} \%$, it is clear that the distribution of silver flakes is loose, suggesting that the contact area between silver particles is not big. This is why the electrical conductivity of the ICAs is poor. For the samples filled with $65 \mathrm{wt} \%$ and $75 \mathrm{wt} \%$ silver flakes, the silver flakes are closer, indicating the filling density increases, that is, the contact area increases between particles.

Fig.7 shows SEM images of the ICAs filled with $65 \mathrm{wt} \%$ and $75 \mathrm{wt} \%$ silver flakes cured at $250{ }^{\circ} \mathrm{C}$. Compared with Fig.6, the silver flakes are closer. The result could be attributed to the phenomenon that the crosslinking reaction of epoxy resin is gradually intensified with increasing of the curing temperature, and the curing shrinkage increases in the contact area between the fillers.

Fig.8 shows resistivity of the ICAs with loading of 75 wt $\%$ cured at $120{ }^{\circ} \mathrm{C} / 90 \mathrm{~min}, 130{ }^{\circ} \mathrm{C} / 60 \mathrm{~min}, 140{ }^{\circ} \mathrm{C} / 60$ $\min , 150{ }^{\circ} \mathrm{C} / 60 \mathrm{~min}, 160{ }^{\circ} \mathrm{C} / 40 \mathrm{~min}, 170{ }^{\circ} \mathrm{C} / 30 \mathrm{~min}, 180$ ${ }^{\circ} \mathrm{C} / 30 \mathrm{~min}, 200{ }^{\circ} \mathrm{C} / 30 \mathrm{~min}$, and $250{ }^{\circ} \mathrm{C} / 30 \mathrm{~min}$. It is clear that the resistivity of the ICAs cured at $120{ }^{\circ} \mathrm{C} / 90 \mathrm{~min}$ is lower than those cured at $130{ }^{\circ} \mathrm{C} / 60 \mathrm{~min}, 140{ }^{\circ} \mathrm{C} / 60 \mathrm{~min}$, $150{ }^{\circ} \mathrm{C} / 60 \mathrm{~min}, 160{ }^{\circ} \mathrm{C} / 40 \mathrm{~min}, 170{ }^{\circ} \mathrm{C} / 30 \mathrm{~min}$, and is similar to the resistivity of the ICAs cured at $180{ }^{\circ} \mathrm{C} / 30$ min. The resistivity of the ICAs cured at $250{ }^{\circ} \mathrm{C} / 30 \mathrm{~min}$ reaches to $3.5 \times 10^{-5} \Omega \cdot \mathrm{cm}$. It suggests that the ICAs cured at low temperature for long time or at high temperature are good to obtain the high electrical conductivity. The reason is that for the ICAs cured in those conditions, the crosslinking density of the epoxy resin can be improved, thus prompting the formation of the conductive network among the fillers.

The internal stress in the adhesive binder plays an important role in determining several properties of the ICA, including its electrical properties. The magnitude of the

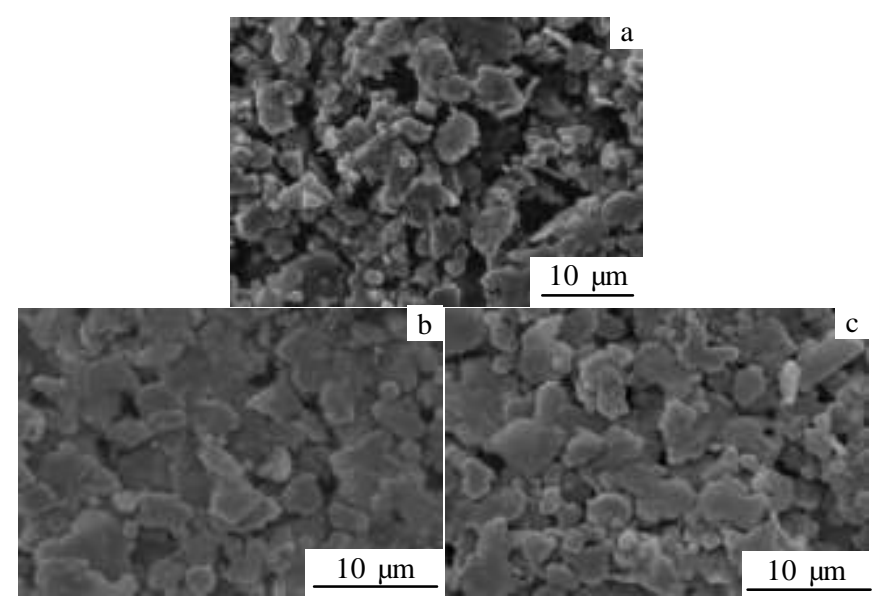

Fig.6 SEM images of the ICAs with $55 \mathrm{wt} \%$ (a), $65 \mathrm{wt} \%$ (b) and $75 \mathrm{wt} \%$ (c) loading cured at $180{ }^{\circ} \mathrm{C}$

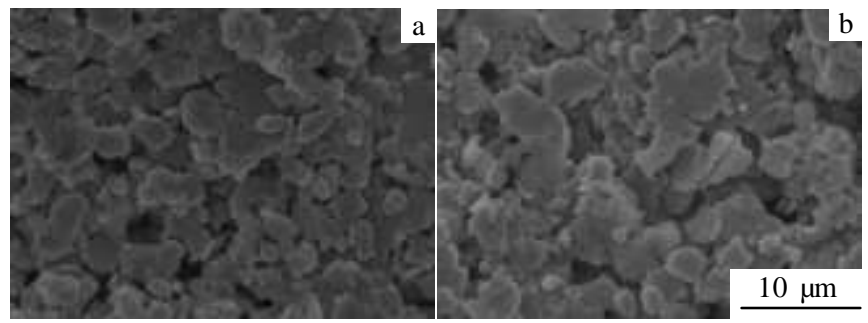

Fig.7 SEM images of the ICAs filled with $65 \mathrm{wt} \%$ (a) and 75 wt $\%$ (b) silver flakes cured at $250{ }^{\circ} \mathrm{C}$

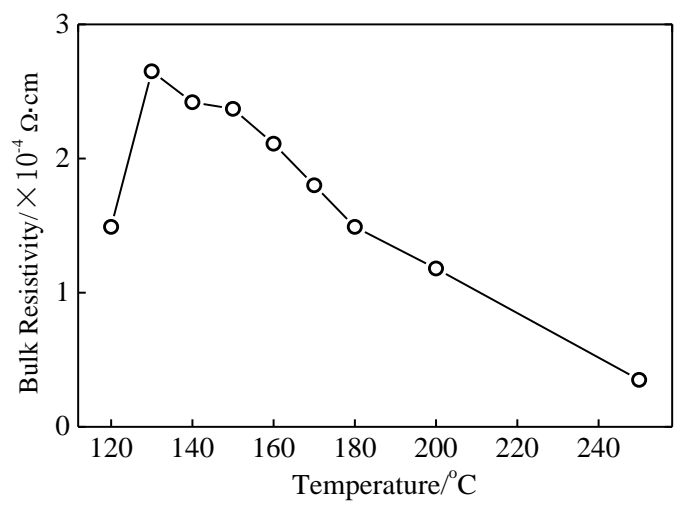

Fig.8 Resistivity of the ICAs with filling loading of $75 \mathrm{wt} \%$ cured at $120^{\circ} \mathrm{C} / 90 \mathrm{~min}, 130{ }^{\circ} \mathrm{C} / 60 \mathrm{~min}, 140{ }^{\circ} \mathrm{C} / 60 \mathrm{~min}$, $150{ }^{\circ} \mathrm{C} / 60 \min , 160{ }^{\circ} \mathrm{C} / 40 \min , 170{ }^{\circ} \mathrm{C} / 30 \mathrm{~min}, 180^{\circ} \mathrm{C} / 30$ $\min , 200^{\circ} \mathrm{C} / 30 \mathrm{~min}$, and $250^{\circ} \mathrm{C} / 30 \mathrm{~min}$

internal stress generated through the curing and cooling processes is considered to be strongly influenced by various characteristics of the polymer structure of the binder. Temperature and time are two important process parameters during curing for controlling the polymer structure. Therefore, the curing procedure should be taken into account as an influence factor, in addition to the degree of conversion of the binder, when an assessment of the reliability of interconnects using ICA is being conducted ${ }^{[11]}$.

\section{Conclusions}

1) There is a great influence of the curing temperature on $55 \%$ silver fill loading, and the volume resistivity of ICAs decreases to $4.5 \times 10^{-3} \Omega \cdot \mathrm{cm}$ from $5.2 \times 10^{-2} \Omega \cdot \mathrm{cm}$ cured at 180 and $250{ }^{\circ} \mathrm{C}$, respectively. However, there is almost no effect on the high silver loading.

2) The resistance reaches to $1.99 \times 10^{6} \Omega$ at $180{ }^{\circ} \mathrm{C}$ after cured for $27 \mathrm{~min}, 1.39 \times 10^{3} \Omega$ for $40 \mathrm{~min}$, and $18.8 \Omega$ for 60 min and the cooling process has almost no effect on the electrical resistance of the ICAs.

3) The ICAs cured at low temperature for long time or at high temperature are good to obtain high electrical conductivity. It could be attributed to the enhancement of the curing shrinkage under those conditions, and it is advantageous to promote the formation of the conductive pathways. 


\section{References}

1 Lin Y C, Zhong Jue. Journal of Electronic Materials[J], 2008, 43: 3072

2 Jiang H, Moon K, Li Y et al. Chemity Mateial[J], 2006, 18(13): 2969

3 Zhang Z X, Chen X Y, Xiao F. Journal of Adhesion Science and Technology[J], 2011, 25: 1465

4 Seo D S, Park S H, Lee J K. Current Applied Physics[J], 2009, 9: S72

5 Cui H, Fan Q, Li D. Polymer International[J], 2013, 62: 1644

6 Yim B S, Kim J M. Materials Transactions[J], 2010, 51(12): 2329

7 Zhang R, Lin W, Moon K et al. Applied Materials and Interfaces[J], 2010, 2(9): 2637
8 Durairaj R, Lam W, Liew J et al. Engineering Letters[J], 2013, 21: 143

9 Falat T, Felba J. International Conference of IMAPS Poland Chapter[C]. Krakow, Poland: IMAPS, 2006: 24

10 Inoue M, Sugamuma K. Soldering \& Surface Mount Technology[J], 2006, 18(2): 40

11 Inoue M, Muta H, Markawa $\mathrm{T}$ et al. Journal of Electronic Materials[J], 2008, 37(4): 462

12 Inoue M, Sugamuma K. Journal of Electronic Materials[J], 2007, 36(6): 669

13 Gao H, Liu L, Luo Y Y et al. International Journal of Polymeric Materials[J], 2011, 60: 409

$14 \mathrm{Lu} \mathrm{D}$, Wong C P. International Journal of Adhesion \& Adhesives[J], 2000, 20: 189

\title{
固化工艺对树脂基导电胶电性能的影响
}

\author{
熊娜娜 ${ }^{1}$, 李志凌 ${ }^{1}$, 谢 辉 $^{2}$, 赵玉珍 ${ }^{3}$, 王悦辉 ${ }^{2}$, 李晶泽 ${ }^{1}$ \\ (1. 电子科技大学 电子薄膜与集成器件国家重点实验室, 四川 成都 610054)
}

(2. 电子科技大学 中山学院, 广东 中山 528402)

(3. 清华大学, 北京 100084)

\begin{abstract}
摘 要: 以微米银片为导电填料制备了环氧树脂基各向异性导电胶, 研究了固化工艺对导电胶电性能的影响。研究结果表明, 固化工艺 对银粉填量为 $55 \%$ (质量分数) 的导电胶影响较大。当固化温度为 $180^{\circ} \mathrm{C}$ 时, 体积电阻率是 $5.2 \times 10^{-2} \Omega \cdot \mathrm{cm}$, 当固化温度为 $250{ }^{\circ} \mathrm{C}$ 时, 体积 电阻率下降到 $4.5 \times 10^{-3} \Omega \cdot \mathrm{cm}$. 然而, 固化温度对高银粉填量的导电胶的影响较小。原位监测 $65 \%$ 的各向异性导电胶的固化过程中的电性 能, 发现固化 $27 \mathrm{~min}$ 后体系温度是 $180^{\circ} \mathrm{C}$, 此时的电阻是 $1.99 \times 10^{6} \Omega, 40 \mathrm{~min}$ 后的电阻是 $1.39 \times 10^{3} \Omega, 60 \mathrm{~min}$ 后的电阻是 $18.8 \Omega$, 冷却时, 导电胶的电阻几乎不变化。采用扫描电阻显微镜分析了银粉在树脂基体中的分布, 进而讨论了固化温度对体积电阻率的影响机制。
\end{abstract} 关键词: 各向异性导电胶; 固化; 体积电阻率; 银片

作者简介: 熊娜娜, 女, 1989 年生, 硕士, 电子科技大学微电子与固体电子学院, 四川 成都 610054, E-mail: xingnnzsedu@ $126 . c o m ~$ 